\begin{tabular}{|c|c|}
\hline & $\begin{array}{l}\text { International Journal of Trend in Scientific } \\
\text { Research and Development (IJTSRD) }\end{array}$ \\
\hline 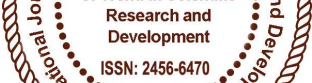 & International Open Access Journal \\
\hline 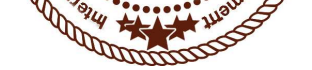 & ISSN No: 2456 - 6470 | www.ijtsrd.com | Volume - 2 | Issue - 2 \\
\hline
\end{tabular}

\title{
Making the cities green: Ecological restoration of degraded urban areas using green infrastructure implications
}

\begin{abstract}
Salman Ali
Green Architecture Research Center, School of

Architecture and Urban Planning, Huazhong

University of Science and Technology, Wuhan, China

\section{ABSTRACT}

The ecological functions of urban areas are degraded; the infrastructures of cities and the built-up regions have enormous impacts on ecosystems and ecology of the urban environment. In this paper, we focused on the connections of urban ecology and urban design, urbanisation impacts on urban ecosystems functions and ecological urbanism approach to degraded urban areas. The studies revealed the relationship of urban ecology and urban design and the ecosystem services they provide in the urban environment. In modern cities the impacts of urbanisation on ecosystem and ecology are various. Many cities in the world have implemented green infrastructure strategies for environmental improvement. Green infrastructure like green spaces, parks, gardens, and green building provide ecosystem services to urban areas and can restore the ecological functions of urban areas. We proposed that Green infrastructure implications at urban design and buildings design level can lead to ecological-urbanism practices and can reduce the environmental problems in degraded urban areas.
\end{abstract}

\author{
Li Baofeng \\ Green Architecture Research Center, School of \\ Architecture and Urban Planning, Huazhong \\ University of Science and Technology, Wuhan, China
}

Keywords: urban ecology, ecosystems services, builtup areas, urban infrastructure, Eco-buildings

\section{Introduction}

The world is facing environmental, social and demographic challenges, which have substantial consequences for cities and their development as well as their ecological functioning in urban areas(Niemelä 2014). The $21^{\text {st }}$ century three most critical dramatic challenges that face human being are population growth; at the beginning of $20^{\text {th }}$ century, the population was 1.6 billion, now over 7 billion. Urban population growth; half of the world's population is urban, this shift is dramatic in China, (Steiner 2014) and the changes in the urban ecosystem at the global scale (Barnosky, Hadly et al. 2012). The essential ecological services to society in urban areas changes because of human activities (Chapin, Power et al. 2011). The most fundamental ecosystems changes due to human activities are land-use and shape of our built environment. These three challenges need more changes in the planning and designing of regions, cities, landscapes, and communities. The urban planners, architects and landscape designer should be well-prepared to this task (Chapin, Power et al. 2011). Urban and suburban areas are distinctive ecosystems because of human-created structures and natural elements, and they are retained and evolved by complicated ecological and social interactions. The amount and degree of environmental impacts of a modern human settlement are tremendous as compared to early times. Furthermore, the developments and expansion of urban environments have significant impacts on native natural habitat which results in the degradation of local, regional, and global biodiversity (McDonnell 2015). Therefore, modern cities and towns facing a variety of environmental and social problems such as pollution of air and water, energy demands, lack of food and poor waste management, which is influencing human well-being (Un-habitat 2010). In the face of these changes, an important question is how to plan and 
manage urban green spaces for the benefit of the city residents and its ecology. Green infrastructure concept addresses this issue in a new way, which broadly focusing on the interconnected network of green spaces and water supporting biodiversity to produce ecosystem services (Pauleit, Liu et al. 2011),(Ahern, Cilliers et al. 2014). The role of urban ecology and green spaces has already addressed through mitigation and adaptation measure in cities. The city's green infrastructure such as green-belts, street trees, and other green areas has a significant function in climate change adaptation measure (Niemelä 2014). The urban green provides many ecosystem services for people such as improve the physical and physiological health of urban dwellers (Tzoulas, Korpela et al. 2007),(Breuste 2011). Therefore, how can cities of future economic, housing and environmental demands are enhanced through design and management of urban green spaces (James, Tzoulas et al. 2009).

To solve these challenges, the integration of ecological approaches in urban design, the role of green infrastructure, and the renewal of environmentally degraded urban places must design according to environmental and ecological principles. The green design implementation at different levels in urban areas can address the challenges that we are facing in the urban environment. The green infrastructure implications have the potential to promote the ecology of cities. Green infrastructure implementation at city level as well as individual building design level should integrate in the built environment to mitigate the influence of urban environment on the urban natural environment.

This paper focuses on the implication of ecological urbanism approaches in the degraded urban environment and their restoration through green infrastructure provisions. We first find the relationship of urban ecology and urban design; many studies show the cities and their ecologies connections. Then, we examine impacts of urbanisation on urban ecology and ecosystems. After discovering the effects of built form on natural ecosystems studies different case studies of cities and environment and their enhancement through ecological processes. Finally, concludes by enhancing urban structure and environment by green infrastructures implication at urban and building design level. The research addressed the following questions;

1. What is urban ecology and how it is related with cities?
2. How ecosystem services are related to cities and built environment?

3. How does urbanisation impacts on urban ecosystem and ecology?

4. How urban ecological designs approaches restore degraded urban environments?

5. How can green infrastructures support ecological urbanism?

\section{Urban ecology relationship with built environment}

There are undoubtedly various definitions of what is "urban"; therefore, a unified definition of urban ecology is nowhere to be found. Additionally, finding an accepted definition for urban or urban ecology may be neither valuable nor necessary ( $\mathrm{Wu} 2014$ ). The history of urban ecology started in 1920 when it becomes part of the human ecology and in late 1940 bio-ecologist stated different version of urban ecology, in the past several similar approaches in urban ecology, progressed with little interaction but, in recent times, different perspectives integrate it. Therefore, now urban ecology becomes familiar in ecology (McDonnell 2011). The various ideas and perspectives in urban ecology are usually classified as either "ecology in cities" which concentrates mainly on the non-human organisms in the urban environment or "ecology of cities," which perceives the whole city as a habitat. Considering the new improvements in urban studies during the past decade, several distinct but related urban environmental approaches can be found (Grimm, Faeth et al. 2008). The four of them are summarized and illustrated below.

First, the human ecology-based or urban sociological approach investigates the behavior of human beings and social organization in cities depending on borrowed ecological theory and ideas (e.g., this method deals with human ecology). Second, the bioecology approach targets the allocation of natural elements like plants and animals around urban areas (e.g., the previous European research). Third, the public mechanism method or human habitat approach both consider the urban area overall as an ecosystem comprises of natural and socioeconomic components (Odum 1983),(McDonnell and Pickett 1990). Fourth, the city landscape approach considers city areas as multi-scaled, spatially different and dynamic parts systems based on principles and methods of landscape ecology. This kind of attitude focuses on the 
connection between ecological processes and urbanization patterns (Odum 1983),(McDonnell and Pickett 1990),(Grimm, Grove et al. 2000).

In urban environments, the interaction between humans and natural processes results in changing of climate, soils, hydrology, a flow of materials and energy, and also in plant and animal habitats (McDonnell, Hahs et al. 2009). Additionally, the perception that urban areas are separated from natural environments and how it is developing created environmental problems and persistent aesthetic ugliness (Spirn 1985). The scarcity of research in urban ecology, biotic consequences of land conversion due to urban areas need better understanding (McDonnell, Hahs et al. 2009),(Niemela, Breuste et al. 2011). Comprehensive knowledge of urban ecosystem structure and function is required (McDonnell, Breuste et al. 2009). Recent studies show that better understanding is not enough we need a perfect understanding of ecological patterns in cities instead of an interplay between nature and people (McDonnell, Hahs et al. 2009),(Niemela, Breuste et al. 2011).

The ecosystems service refers to delivery, protection of goods and benefits that humans obtain from ecosystem functions. (Assessment 2003),(De Groot, Wilson et al. 2002),(Bolund and Hunhammar 1999). Ecosystem services concept is an emerging concept among critics and skeptics within the ecological design and planning communities. It provides direct service, such as air, minerals, food, water, and energy, environmental regulation, i.e., purifications of water, carbon sequestration, climate mitigation, waste decomposition, and detoxification. Besides environmental benefits, it also provides intellectual inspiration, recreation, ecotourism, and scientific discovery (Steiner 2014). McHarg in his projects and his ecological wisdom seeks the natural carrying capacity of land through a design process that respects, integrates, and facilitates multiple ecosystem processes, functions, and services (Yang and $\mathrm{Li}$ 2016). Also, In 2005, the United Nation stressed the value of ecosystem services, focused on the linkages between ecosystems and human well-being (Assessment 2005). In 2012, the ecosystem services concept was being applied to landscape design through the sustainable site's initiative (SITES)(Calkins 2012),(Steiner 2011),(Venhaus 2012).
Urbanisation has many components like population; increase in number and density of people, and the landscape component; the growth of built-up space with accompanying infrastructures(Shi and Yu 2014). In urban areas not only the population has been increased but also the built structures which result in the reduction of urban ecology. It appears that a closer integration of human-made built environment and ecological environment approach is still in its early stages. Urban Ecology is embedded in the life and structure of urban region such a holistic ecology of urban areas(Grimm, Grove et al. 2000), (McDonnell, Breuste et al. 2009),(Niemelä 2014),(Jim 2011) to enhanced urban ecology through design has been proposed.

\section{Impacts of urbanisation on urban ecosystem}

The concept of perfect city form has a long history in western theories of urbanism. City sociology's empiricists start using scientific research to express the impacts of urbanization on human habitat as well as city form (Haar 2007). The urbanized world now consists of $50 \%$ of the world populations due to the rapid scale of urban expansion (Wu 2008). Despite the fact that, the built environmental feature in urbanized areas which includes all non-vegetative and human-created elements for example roads, runways, and buildings are small in proportion to the earth's surface area (Schneider, Friedl et al. 2010). However, the impacts of the urban area are prolonged and profound on the local and global level. Urban areas now consume $60 \%$ domestic water, $75 \%$ energy and use $80 \%$ wood in industries, and also emitting $80 \%$ greenhouse gas (Grimm, Faeth et al. 2008). In the twentieth century, the discussion started whether to rebuild current existing cities or to build future cities. Ebenezer Howard, in his book, Garden Cities for ToMorrow present the "Garden cities" concept for new towns while Patrick Geddes who was qualified biologist perceive city and its surroundings through his approach " Here or nowhere is our Utopia" as an organic whole (Spirn 2011).

Modern cities are complex, integrating various sophisticated components, technologies, and processes to perform, which includes different resource distribution systems, communication systems, and essential (food, water, electricity) human servicing systems. These systems have harmful impacts on natural environment because they are human-oriented. As the issue of healthy urban 
environment has increased in the world, more consideration was given to the solutions of these negative impacts. The more integrative approach is necessary between the human beings, natural environment, and in the design and construction of built environment (Ozer 2014). According to the critic author Lewis Mumford, a new sense of form will produce from architecture and urban design when organic understanding of interactive approach of the complex relationship between cities and their surroundings, rural and urban areas is achieved (Mumford 1968). In the designing of urban areas and how to maintain it, the concept that nature is everywhere is vital for health, the safety of their residents. Nature and city must be viewed one entity and the surrounding areas; suburbs are transformed into the natural environment (Spirn 2011). In the pursuit of this kind of integration would be to reduce the harmful impact of human expansion on natural urban environments.

In the last few years, several new approaches in urban design practice have been introduced to minimize the environmental effects by making the connection between ecosystems process and their functions (Dyson and Yocom 2015). One approach is the ecological design which is the result of a complicated relationship with different activities like human, other living creatures and natural process (Spirn 2011). The city should be designed as a whole, including its parks, buildings and urban districts and solutions to the problems should not be separated but consider it as connected through comprehensive plans of the ecosystem. The individual elements can be designed through this frame for multi-purpose with a minimum input of energy and materials (Spirn 1985). The expansion of urban regions due to population increase, the built-up areas provides more opportunities for landscape architects and planners for regeneration and renewal concerning working on urban ecology. The ecological urbanism offers an alternative organic concept; suggesting that landscape should replace transportation systems and buildings as the principal organizing structure in urban design. It is emphasizing the integration of ecology in city design and planning by establishing frameworks for urban change (Steiner 2014). The prime tasks, in any ecological design endeavor, is usually to prevent further deprivation in the city environment and design to maintain it; eventually, will result in the recovery of the previous ecological conditions that were present before the existing of the industrialized world (Yeang 2006).

The urban degraded places offer boundless opportunities and challenges for regeneration and restoration. How to make these urban sites environmental friendly for people and species as well as conserve energy and water. Furthermore, ecological approaches should be considered in such urban areas projects (Steiner 2014). Further research is required to ecological urbanism approaches and their negative and positive results on the local ecosystem.

\section{Ecological urban design approaches}

Ecological Urbanism has a long history of theories to support it and Practice of built works that demonstrate its benefits (Spirn 1985). According to Ecologists Pickett and Cadenasso (2008), the integration of plant ecology into the design of cities is essential because the present separation of the human and natural system is incorrect. In the shaping of the cities, natural environment researcher should take an active part with city designer instead of passive observers. This kind of approach relates urban form to natural process not only using local materials and imitating the shape of physical features. Urban designers and planners can find possibilities and can transform changes and can connect separate elements by focusing on the process that shape and structure the environment (Ozer 2014). The ecological theories view cities as spatially heterogeneous landscape composed of multiple interacting patches, and an art component is needed to integrate ecology, planning, design and management (Wu 2008).

An ecological design approach for cities, which is not new, is a strategy for city design change and its future. Many progressive cities have already got current ecological sustainable plans and strategies for the greening of the city environment. However, most of those methods and procedures are simple and pragmatic, which focus on reduction of energy or on the addition of green areas. The principal question is: can such kinds of initiatives be transformed by the approach of the ecological urbanism? British architecture Historian Reyner Banham, criticize that the form of city fewer matters as far as it works (Mostafavi and Doherty 2010). 
In the planning of cities, urban ecological infrastructure enhances the green space systems because it includes spatially all natural, semi-natural and artificial networks of multifunctional ecological systems within, around and between urban areas. The idea of Ecological Infrastructure emphasizes the quality along with a quantity of urban and peri-urban green spaces, their multifunctional role, and the importance of interconnections between habitats (Sandstro“ m 2002), (TURNER 1996). The understanding of large-scale systems from McHarg ideas of broader regional planning, provide the basis for landscape urbanism and initiate ecological and social dynamics which brings people closer to nature (Steiner 2014).

Ecology and green spaces must be incorporated into the planning for achieving improved urban sustainability (Childers, Pickett et al. 2014). And the related issue of what is the possibilities and challenges for integrating green spaces into planning and design, and how ecosystem services are contributing to urban sustainability (Niemelä 2014).

\section{Ecological integration; provisions of green infrastructures}

Green infrastructure refers to an interconnected network of multifunctional green spaces that are strategically planned and managed to provide a range of ecological, social and economic benefits (Benedict and McMahon 2012),(Kambites and Owen 2006),(Tzoulas, Korpela et al. 2007),(Wright 2011). Green infrastructure examples are urban forests, public parks, community gardens, urban wetlands, green alleys and streets, permeable vegetated surfaces, and green roofs (Byrne and Jinjun 2009), (Douglas 2011),(Foster, Lowe et al. 2011),(Gill, Handley et al. 2007),(Klemm, Heusinkveld et al. 2015). Green infrastructure can potentially improve the environment by lowering wind speeds, reduce stormwater run-off, modulate ambient temperature, reduce energy use and sequester carbon, among other ecosystem service benefits (Mell 2013),(Mell, Henneberry et al. 2013),(Roy, Byrne et al. 2012).

The Green Infrastructure to upgrade urban areas consist of natural, semi-natural and artificial networks of the multifunctional ecological system within, around, and between urban areas, at all spatial scales (Sandstro“ m 2002), (Tzoulas, Korpela et al. 2007). If planned, developed, and maintained can guide urban development by providing a framework for nature conservation. (Walmsley 2006),(Schrijnen 2000),(Vander Ryn and Cowan 1996). Furthermore, maintains the integrity of habitat systems and provide the physical basis for ecological networks in urban areas. (Tzoulas, Korpela et al. 2007).

Urban infrastructure like roads, bridges, highways, parks, and corridors supports cities life, and conservation of natural landscape areas and water bodies of urban sites is necessary for the survival of native species and natural ecology (Haar 2007). The essential elements of environmentally friendly infrastructure can promote ecosystem health in a variety of ways. Urban and peri-urban habitats boost the overall vegetation cover (natural, semi-natural and artificial), thus resulting in conservation of biodiversity which encourages ecosystem services and processes (Costanza, Norton et al. 1992),(Flores, Pickett et al. 1998). Therefore, Green infrastructure can contribute to ecological functions and ecosystem services (Tzoulas, Korpela et al. 2007).

\section{I- Green infrastructure at urban level}

Green infrastructure is based on ecological theory and principles, both specific and broad research in urban areas is required to answer the question, how green infrastructure can support biodiversity and adapt cities to climate change (Pauleit, Liu et al. 2011). Green spaces in urban areas are crucial for the residents because of ecosystem services (Alfsen, DuVal et al. 2011). And these services are substantially depending upon proper urban level planning (Colding 2011). However, neither the understandings of providing these services is yet fully understood, nor the knowledge that considers ecosystem services is currently sufficient (Niemelä, Saarela et al. 2010),(James, Tzoulas et al. 2009). Multiplediscipline experts should address urban areas challenges of waste and storm-water systems in the face of climate change, wetland restoration, and the re-integration of such spaces into the urban green infrastructure (Pauleit, Liu et al. 2011).

Urban connectivity which is created through connection related features like transportation and energy distribution systems can provide ecosystem services like buffering and maintaining urban hydrology. Ecological networks, parks, river ways, and other networks like blue-green networks often contribute to urban connectivity ecosystems. Ecological landscape theory and principles are 
significantly applied in the planning and designing of these systems. Also, These networks are more popular these days due to the connectivity- based functions like hydrology, transportation, and urban mobility (Bryant 2006). There is a wide range of adaptive strategies to converts urban infrastructure spaces such as rail corridors, underutilized alleys, streets, abandoned transport, and brown-fields. For example in many cities of United States, planners are transforming back alleys into green spaces for social and environmental and ecological benefits (Newell, Seymour et al. 2013).

Several cities are enthusiastically involved in "urban greening" projects intended to address urban impacts and to make urban areas healthier, attractive and biodiverse. One example is the New York City's initiative "Designing the Edge" is a modern program that is created for rebuilding biodiversity to urban waterfronts. In this project, NYC Park's designers designed a new waterfront that is highly engaging, porous and sustainable (Ahern 2013). Another example is the Houtan Park in Shanghai, China here highly contaminated river water before discharging into the same river is improved through series of treatment. This park also provides natural habitat, floodwater storage and public recreation for locals (Rottle and Yocom 2011). Additionally, two examples which integrate ecology and city design presented by landscape urbanism are Freshkills Park and The High Line project. (Steiner 2014) Another successful example of a multifunctional ecological network is the Emscher Park in the Rhur and Rhine valleys; the polluted rivers of Europe are transformed into the environment-friendly and cultural corridor by providing functions like a river, habitat restoration, as well as, bicycle transportations (Ruhr 2010), (Rottle and Yocom 2011). The most famous example of transforming urban infrastructure to environmental and ecological space is the New York's High Line; was ready for demolition but rescued by local activists and redesigned as a greenway (Wolch, Byrne et al. 2014).

\section{II- Green infrastructure integration at building design level}

The foundation of building

design is to make shelter, creating a refuge, in marking the place of human beings within a natural environment. Thus, designer become architects of the environment when making spaces for such organization that forms our interaction with one another and with nature (Spirn 1990). In Ecological Design book the author Van Der Ryn and Cowan present five design principles; all integrate Design with ecology, from their years of research and practice. The second principle is evaluating the criteria for ecological impact of building design on the environment. According to them, the ecological environment can be achieved by design buildings according to ecological principles (Cowan and Van Der Ryn 1996). The communities that want more housing, jobs, more open space can use green infrastructure to achieve it (Benedict and McMahon 2012).

In Green Architecture Book, Malcolm Wells (1981) said that better connection between natural environment and built environment could solve environmental problems. While searching for a more climate responsive architecture, he asked this question, "Why is it that almost every architect can identify and appreciate beauty in the natural world and yet so often fail to endow his work with it" (p 41). $\mathrm{He}$ emphasized that the responsibilities of architecture have more than maintaining the environment. ICTe more significant connection between buildings and natural surroundings through natural means can provide moderate climate, animal habitat, and consume building wastes (Ozer 2014). Urban green spaces especially green roofs provide ecosystem services, as in many countries they are built for years, but recent increase of green roofs is because of climate change mitigation. Additionally, the benefits of green roofs for urban dwellers are still little understood (Jungels, Rakow et al. 2013). The importance of designing resilient or climate responsive buildings that mitigate damage to the environment and local climate should be designed for a long-term with low embodied energy. In the designing of individual buildings, energy efficiency related technologies, for example, insulation materials, efficient appliances, and fixtures can minimize the negative impacts of buildings on the environment, but it is considered short term. Beside technological focused based strategies, there is need to find solutions that promote connections to the environment (Ozer 2014).

Many architects have been against of sustainable environment utilizing technologies and written about the relationship between nature and built environment. For example, architect Ken Yeang 
(2007) in his book, Eco-Skyscrapers, have also criticized the conception of technological efficiency and said that gathering enough eco-gadgetry such as photovoltaic solar collectors, insulation facades, recycling and building automation systems will not result in ecological architecture (Ozer 2014). Green spaces are important as they can contribute to the mitigation of climate change, although the carbon dioxide emissions in cities are higher than the amount of carbon sequestered by urban green (McPherson 1994). However, buildings that are under tree shadings reduce carbon dioxide emissions indirectly by ameliorating temperatures as well as reducing the use of air conditioning in summer and heating in the winter (McPherson, Nowak et al. 1994). Designers should recognize the challenges related to project site, context, and programs to find their full impact on the ecosystems because the designer responsibility is beyond the project client's boundaries (Berger 2007). Discussion

Contemporary urban issues are diverse in scale, and each discipline is limited to resolving it especially in most densely populated areas where disciplinary boundaries are harder to identify. The transdisciplinary approach in ecological urbanism is necessary for thinking about the challenging facing our urban environment both currently and in the future (Mostafavi and Doherty 2010). Thus, there is a need to find ways in which these challenges and their consequences can mitigate through ecological urbanism approaches. The current practices in buildings industries are only focusing on technological solutions to the urban problems by reducing the harmful impacts of buildings (Ozer 2014). Much of the work produced as ecological and environmental friendly are poor quality and mainly focused on producing energy and recycling building wastes (Mostafavi and Doherty 2010). There is a need to modify the relationship between nature and built environment. This improved mutual connection between built and natural environment can make both cities and natural systems flourish and prosper.

The field of ecology, in particular, provided the theoretical core for McHarg's ecological planning and design method. His design processes start with a comprehensive ecological inventory, in which natural processes are integrated into planning and design through ecological factors to support human activity and its suitability for a particular type of land use (McHarg 2007). Additionally, the existing standards of design practices are restricted to resolve the problems of ecology and changing the recognized thinking ways. In this background, ecological urbanism will improve the approaches in urban design and development. Ecological urbanism is not entirely new approach; it is the collaborative approach towards urban designing which uses both new and old strategies, methods and techniques in different fields from ecology perspective. These kinds of approaches should retrofit the current urban conditions as well as the future cities plans (Mostafavi and Doherty 2010). Ecological urbanism has grown from the concepts and actions of architecture, landscape architecture, urban planning, and urban designing as presented by theorists and professionals such as those discussed above (Spirn 2011). The proposed ecological urbanism idea by using green infrastructure implications at urban and building level will eliminate the environmental problems in urban degraded places. Conclusions

The global challenges of environmental, social and demographic have substantial impacts on cities and urban environment and their ecosystems. To conclude, the problems of urban ecologies in current built-up areas need more green approaches and spaces to enhance the cities and urban environments. Ecological infrastructure implication at a city level and building level can give great support to ecologies of cities and urban environment. Establishment of cities, urban areas and building typologies on ecological principles could be a way to mitigate the impacts on the built environment on the natural environment. Addressing urban issues from the ecological process could make pattern and process in cities towards ecological urbanism. Ecological design approaches regarding green infrastructure can yield new and innovative urban environment. Furthermore, such an approach can provide useful perspective for urban planners and designers. Further, research should focus on the importance of cultural ecosystem in cities how these services like opportunities for recreation, recuperation from stress and educational possibilities.

\section{References}

1. Ahern, J. (2013). "Urban landscape sustainability and resilience: the promise and challenges of integrating ecology with urban planning and design." Landscape Ecology 28(6): 1203-1212.

2. Ahern, J., S. Cilliers and J. Niemelä (2014). "The concept of ecosystem services in adaptive urban 
planning and design: A framework for supporting innovation." Landscape and Urban Planning 125: 254-259.

3. Alfsen, C., A. DuVal and T. Elmqvist (2011). "The urban landscape as a social-ecological system for governance of ecosystem services."

4. Assessment, M. E. (2003). Assessment: Ecosystems and human well-being: A framework for assessment, Island Press.

5. Assessment, M. E. (2005). "Millennium ecosystem assessment." Ecosystems and human well-being: a framework for assessment Washington, DC: Island Press.

6. Barnosky, A. D., E. A. Hadly, J. Bascompte, E. L. Berlow, J. H. Brown, M. Fortelius, W. M. Getz, J. Harte, A. Hastings and P. A. Marquet (2012). "Approaching a state shift in Earth/'s biosphere." Nature 486(7401): 52-58.

7. Benedict, M. A. and E. T. McMahon (2012). Green infrastructure: linking landscapes and communities, Island Press.

8. Berger, A. (2007). Drosscape: wasting land urban America, Princeton Architectural Press.

9. Bolund, P. and S. Hunhammar (1999). "Ecosystem services in urban areas." Ecological Economics 29(2): 293-301.

10. Breuste, J. H. (2011). Urban ecology: patterns, processes, and applications, Oxford University Press.

11. Bryant, M. M. (2006). "Urban landscape conservation and the role of ecological greenways at local and metropolitan scales." Landscape and urban planning 76(1): 23-44.

12. Byrne, J. and Y. Jinjun (2009). "Can urban greenspace combat climate change? Towards a subtropical cities research agenda." Australian Planner 46(4): 36-43.

13. Calkins, M. (2012). The sustainable sites handbook. Hoboken, NJ: Wiley and Sons.

14. Chapin, F. S., M. E. Power, S. T. Pickett, A. Freitag, J. A. Reynolds, R. B. Jackson, D. M. Lodge, C. Duke, S. L. Collins and A. G. Power (2011). "Earth Stewardship: science for action to sustain the human-earth system." Ecosphere 2(8): $1-20$.

15. Childers, D. L., S. T. Pickett, J. M. Grove, L. Ogden and A. Whitmer (2014). "Advancing urban sustainability theory and action: Challenges and opportunities." Landscape and Urban Planning 125: 320-328.

16. Colding, J. (2011). "The role of ecosystem services in contemporary urban planning."

17. Costanza, R., B. G. Norton and B. D. Haskell (1992). Ecosystem health: new goals for environmental management, Island Press.

18. Cowan, S. and S. Van Der Ryn (1996). "Ecological design." Washington: DC-Covelo.

19. De Groot, R. S., M. A. Wilson and R. M. Boumans (2002). "A typology for the classification, description, and valuation of ecosystem functions, goods, and services." Ecological economics 41(3): 393-408.

20. Douglas, I. (2011). "The role of green infrastructure in adapting cities to climate change." Handbook of urban ecology: 583-588.

21. Dyson, K. and K. Yocom (2015). "Ecological design for urban waterfronts." Urban Ecosystems 18(1): 189-208.

22. Flores, A., S. T. Pickett, W. C. Zipperer, R. V. Pouyat and R. Pirani (1998). "Adopting a modern ecological view of the metropolitan landscape: the case of a greenspace system for the New York City region." Landscape and urban planning 39(4): 295-308.

23. Foster, J., A. Lowe and S. Winkelman (2011). "The value of green infrastructure for urban climate adaptation." Center for Clean Air Policy 750.

24. Gill, S. E., J. F. Handley, A. R. Ennos and S. Pauleit (2007). "Adapting cities for climate change: the role of the green infrastructure." Built environment 33(1): 115-133.

25. Grimm, N. B., S. H. Faeth, N. E. Golubiewski, C. L. Redman, J. Wu, X. Bai and J. M. Briggs (2008). "Global change and the ecology of cities." science 319(5864): 756-760.

26. Grimm, N. B., J. G. Grove, S. T. Pickett and C. L. Redman (2000). "Integrated Approaches to LongTerm Studies of Urban Ecological Systems Urban ecological systems present multiple challenges to ecologists - pervasive human impact and extreme heterogeneity of cities, and the need to integrate social and ecological approaches, concepts, and theory." BioScience 50(7): 571-584.

27. Haar, S. (2007). The ecological city: metaphor versus metabolism, Citeseer. 
28. James, P., K. Tzoulas, M. Adams, A. Barber, J. Box, J. Breuste, T. Elmqvist, M. Frith, C. Gordon and K. Greening (2009). "Towards an integrated understanding of green space in the European built environment." Urban Forestry \& Urban Greening 8(2): 65-75.

29. Jim, C. (2011). "Holistic research agenda for sustainable management and conservation of urban woodlands." Landscape and urban planning 100(4): 375-379.

30. Jungels, J., D. A. Rakow, S. B. Allred and S. M. Skelly (2013). "Attitudes and aesthetic reactions toward green roofs in the Northeastern United States." Landscape and Urban Planning 117: 1321.

31. Kambites, C. and S. Owen (2006). "Renewed prospects for green infrastructure planning in the UK." Planning, Practice \& Research 21(4): 483496.

32. Klemm, W., B. G. Heusinkveld, S. Lenzholzer and B. van Hove (2015). "Street greenery and its physical and psychological impact on thermal comfort." Landscape and Urban Planning 138: 8798.

33. McDonnell, M., J. Breuste and A. Hahs (2009). "Introduction: Scope of the book and need for developing a comparative approach to the ecological study of cities and towns." Ecology of cities and towns: A comparative approach. Cambridge University Press, Cambridge: 1-6.

34. McDonnell, M. J. (2011). "The history of urban ecology: an ecologist's perspective." Urban Ecology: Patterns, Processes, and Applications. Niemelä J., Breuste J., Elmqvist T., Guntenspergen G., James P., McIntyre NE (eds). Oxford University Press, Oxford: 5-13.

35. McDonnell, M. J. (2015). "Journal of Urban Ecology: Linking and promoting research and practice in the evolving discipline of urban ecology." Journal of Urban Ecology 1(1): juv003.

36. McDonnell, M. J., A. K. Hahs and J. H. Breuste (2009). Ecology of cities and towns: a comparative approach, Cambridge University Press.

37. McDonnell, M. J. and S. T. Pickett (1990). "Ecosystem structure and function along urban-rural gradients: an unexploited opportunity for ecology." Ecology 71(4): 1232-1237.
38. McHarg, I. L. (2007). To heal the earth: selected writings of Ian L. McHarg, Island Press.

39. McPherson, E. G. (1994). "Energy-saving potential of trees in Chicago." Chicago's urban forest ecosystem: results of the Chicago Urban Forest Climate Project. Gen. Tech. Rep. NE-186. Radnor [Newtown Square], PA: US Department of Agriculture, Forest Service, Northeastern Research Station: 95-113.

40. McPherson, G. E., D. J. Nowak and R. A. Rowntree (1994). "Chicago's urban forest ecosystem: results of the Chicago Urban Forest Climate Project."

41. Mell, I. C. (2013). "Can you tell a green field from a cold steel rail? Examining the "green" of Green Infrastructure development." Local Environment 18(2): 152-166.

42. Mell, I. C., J. Henneberry, S. Hehl-Lange and B. Keskin (2013). "Promoting urban greening: Valuing the development of green infrastructure investments in the urban core of Manchester, UK." Urban forestry \& urban greening 12(3): 296306.

43. Mostafavi, M. and G. Doherty (2010). Ecological Urbanism. Harvard University Graduate School of Design, Lars Müller Publishers, Baden.

44. Mumford, L. (1968). The urban prospect: essays, New York; Harcourt, Brace \& World.

45. Newell, J. P., M. Seymour, T. Yee, J. Renteria, T. Longcore, J. R. Wolch and A. Shishkovsky (2013). "Green Alley Programs: Planning for a sustainable urban infrastructure?" Cities 31: 144155.

46. Niemelä, J. (2014). "Ecology of urban green spaces: The way forward in answering major research questions." Landscape and Urban Planning 125: 298-303.

47. Niemela, J., J. Breuste, T. Elmqvist, G. R. Guntenspergen, P. James and N. McIntyre (2011). "Concluding remarks: The way forward for urban ecology."

48. Niemelä, J., S.-R. Saarela, T. Söderman, L. Kopperoinen, V. Yli-Pelkonen, S. Väre and D. J. Kotze (2010). "Using the ecosystem services approach for better planning and conservation of urban green spaces: a Finland case study." Biodiversity and Conservation 19(11): 3225-3243.

49. Odum, H. T. (1983). "Systems Ecology; an introduction." 
50. Ozer, E. (2014). "Mutualistic relationships versus hyper-efficiencies in the sustainable building and city." Urban Ecosystems 17(1): 195-204.

51. Pauleit, S., L. Liu, J. Ahern and A. Kazmierczak (2011). "Multifunctional green infrastructure planning to promote ecological services in the city."

52. Rottle, N. and K. Yocom (2011). Basics Landscape Architecture 02: Ecological Design, A\&C Black.

53. Roy, S., J. Byrne and C. Pickering (2012). "A systematic quantitative review of urban tree benefits, costs, and assessment methods across cities in different climatic zones." Urban Forestry \& Urban Greening 11(4): 351-363.

54. Ruhr, R. (2010). Unter freiem Himmel/Under the Open Sky: Emscher Landschaftspark/Emscher Landscape Park, Walter de Gruyter.

55. Sandstro“ m, U. G. (2002). "Green infrastructure planning in urban Sweden." Planning Practice and Research 17(4): 373-385.

56. Schneider, A., M. A. Friedl and D. Potere (2010). "Mapping global urban areas using MODIS 500m data: New methods and datasets based on 'urban ecoregions."' Remote Sensing of Environment 114(8): 1733-1746.

57. Schrijnen, P. M. (2000). "Infrastructure networks and red-green patterns in city regions." Landscape and Urban Planning 48(3): 191-204.

58. Shi, P. and D. Yu (2014). "Assessing urban environmental resources and services of Shenzhen, China: A landscape-based approach for urban planning and sustainability." Landscape and Urban Planning 125: 290-297.

59. Spirn, A. W. (1985). The granite garden: urban nature and human design, Basic Books.

60. Spirn, A. W. (1985). "Urban nature and human design: renewing the great tradition." Journal of Planning Education and Research 5(1): 39-51.

61. Spirn, A. W. (1990). "Toward A Unified Vision: Architecture In The Landscape." Landscape Architecture 80(8): 36-41.

62. Spirn, A. W. (2011). "Ecological urbanism: a framework for the design of resilient cities."

63. Steiner, F. (2011). Design for a vulnerable planet, University of Texas Press.
64. Steiner, F. (2014). "Frontiers in urban ecological design and planning research." Landscape and urban planning 125: 304-311.

65. TURNER, T. (1996). "City as landscape: a postPostmodern view of planning and design." London, Spon.

66. Tzoulas, K., K. Korpela, S. Venn, V. Yli-Pelkonen, A. Kaźmierczak, J. Niemela and P. James (2007). "Promoting ecosystem and human health in urban areas using Green Infrastructure: A literature review." Landscape and urban planning 81(3): 167-178.

67. Un-habitat (2010). State of the world's cities 2010/2011: bridging the urban divide, Earthscan.

68. Vander Ryn, S. and S. Cowan (1996). "Ecological Design Island Press Washington." DC Google Scholar.

69. Venhaus, H. (2012). Designing the Sustainable Site: Integrated Design Strategies for Small Scale Sites and Residential Landscapes, John Wiley \& Sons.

70. Walmsley, A. (2006). "Greenways: multiplying and diversifying in the 21 st century." Landscape and urban planning 76(1): 252-290.

71. Wolch, J. R., J. Byrne and J. P. Newell (2014). "Urban green space, public health, and environmental justice: The challenge of making cities 'just green enough'." Landscape and Urban Planning 125: 234-244.

72. Wright, H. (2011). "Understanding green infrastructure: the development of a contested concept in England." Local Environment 16(10): 1003-1019.

73. Wu, J. (2014). "Urban ecology and sustainability: The state-of-the-science and future directions." Landscape and Urban Planning 125: 209-221.

74. Wu, J. J. (2008). "Making the case for landscape ecology an effective approach to urban sustainability." Landscape Journal 27(1): 41-50.

75. Yang, B. and S. Li (2016). "Design with Nature: Ian McHarg's ecological wisdom as actionable and practical knowledge." Landscape and Urban Planning 155: 21-32.

76. Yeang, K. (2006). "Ecodesign: A manual for ecological design." 